\title{
Cartography for the Aquifer Potential Recharge Areas of the Base of the Department of Aboisso (South-East Côte d'Ivoire)
}

\author{
Gabriel Etienne Ake ${ }^{1 *}$, Kan Jean Kouame ${ }^{1,2}$, Daouda Fofana1, \\ Oularé Sekouba ${ }^{1,2}$, Affoué Bénédicte Koffi ${ }^{1}$, Jean Patrice Jourda ${ }^{1,2}$
}

\begin{abstract}
${ }^{1}$ Laboratory of Science and Technology of Water and Environment (LSTWE), UFR of Earth Sciences and Mineral Resources, University of Félix Houphouët-Boigny, Abidjan, Côte d'Ivoire

${ }^{2}$ University Center for Research and Application in Remote Sensing (UCRARS), Abidjan, Côte d'Ivoire

Email:*ak_gabe@yahoo.fr, jeankkan@yahoo.fr, daoudafof1991@gmail.com,oulare_sekouba@yahoo.fr, benedicteka@gmail.com, jourda_patrice@yahoo.fr
\end{abstract}

How to cite this paper: Ake, G. E., Kouame, K. J., Fofana, D., Sekouba, O., Koffi, A. B., \& Jourda, J. P. (2019). Cartography for the Aquifer Potential Recharge Areas of the Base of the Department of Aboisso (South-East Côte d'Ivoire). Journal of Geoscience and Environment Protection, 7, 49-68.

https://doi.org/10.4236/gep.2019.78004

Received: May 14, 2019

Accepted: August 9, 2019

Published: August 12, 2019

Copyright (อ 2019 by author(s) and Scientific Research Publishing Inc. This work is licensed under the Creative Commons Attribution International License (CC BY 4.0).

http://creativecommons.org/licenses/by/4.0/ (c) (i) Open Access

\begin{abstract}
The study highlights the potential recharge areas of the aquifers of the Department of Aboisso for an adequate and rational management of their use. The methodology used consisted in the identification of parameters (land use, soil types, drainage density, slope, induced permeability and alteration thickness) allowing infiltration and their expression as thematic maps. A weighting of these parameters was made by the multicriteria analysis method of Saaty. The integration to GIS conducted to elaborate the map of the potential recharge area of the aquifers for the Department of Aboisso. It brings to light five recharge level classes (bad: 20\%; mediocre: 19\%, medium: $45 \%$; good: $15 \%$ and very good: $1 \%$ ) in the study area. That map reveals the dominance of good recharge areas covering $61 \%$ and practically all over the studied area. They are generally characterized with gentle slopes coupled with mosaics of cultivations and forests, and high induced permeability allowing better infiltration. The zones of low recharge cover $39 \%$ of the department's area, and are mainly located in urban areas inside the streams. This study exhibited that the land use is the preponderant parameter influencing the recharge in base area. This map could be considered as an excellent support for all kinds of activities especially to implement planning in the Department of Aboisso, the setting up of drilling broadbands and the choice of future sites for landfills or landfill of wastes to protect groundwater from any pollution.
\end{abstract}

\section{Keywords}

Recharge, Cartography, Multicriteria Analysis, Aboisso, Côte d'Ivoire 


\section{Introduction}

Over the sedimentary coast basin, the underground resources of Côte d'Ivoire are limited. For that reason, most cities apart from the capital are supplied with drinkable water from the surface water. For times, these surface waters run up to dryness due to rainfall decrease causing by the climate change, the development of anthropology activities impacting negatively the resources mobilization.

Pollution problems encountered at the Terminal Continental groundwater in Abidjan led authorities to research new sources by exploring the groundwater of Bonoua. The capacity of that groundwater is estimated at about 13.9 billion $\mathrm{m}^{3}$ of water (Aké, 2001). It serves for drinking water supply (DWS) in Bonoua, Grand Bassam and Southern part of Abidjan (Port-Bouët, Koumassi, Marcory and Treichville). Previous works, those of Koffi (2016), Aké et al., (2018) were conducted relating to the cartography of the recharge in sedimentary area. That cartography focused on five parameters: the land use, the land types, the density of drainage, the slope and the geological formations.

The present study is a contribution to previous works, making them better by adding two other parameters (the alteration thickness and the induced permeability) in base area excluding a new variable named "geological formation". The variability of these several parameters needs their integration or combination together to make the multicriteria analysis of the recharge areas possible. Geographical Information Systems (GIS) are generally used for integrating thematic maps with sufficient precision at a reasonable delay. Spatial techniques gain advantages to cover areas of hundreds or thousands of $\mathrm{km}^{2}$ for lower costs. That helps seize the spatial variability of the recharge areas at a regional scale (Oularé et al., 2014).

Many problems of drinkable water are encountered in the Department of Aboisso, as it's the case for most of the Ivorian cities. In fact, the surface water (river Bia) treated by the Water Supply Society of Côte d'Ivoire (WSSCI) cannot cover people's drinkable water demand in the Department.

That brings a part of the population to exploit water from traditional wells, backwaters, intermittent streams, which have poor quality because they are very vulnerable to pollution (Dibi, 2008).

The area of Aboisso is well watered with a higher rainfall (about $2000 \mathrm{~mm}$ ). Thus it's necessary to identify the recharge areas of aquifers by using cartography, in a mind of covering properly water demand of the population and to protect them.

Indeed, without recharge there is no groundwater, so one of the key parameters to its sustainability namely recharge is currently one of the major concerns of the scientific community and decision-makers (Haouchine et al., 2010).

The evaluation of the groundwater recharge is certainly one of the more relevant parameters. Conversely it's also the most difficult to do. However various approaches have been considered (Sophocleous, 2004).

These ones can be classified in climatic, direct, physical and geochemical me- 
thods. But, they remain insufficient regarding the expected results.

This study aims at highlighting the potential recharge areas of the aquifers of the Department of Aboisso for a rational and an adequate management of their use. It includes a cartographic approach and GIS coupled with a multicriteria analysis of Saaty.

\section{Presentation of the Study Area}

The Department of Aboisso is located in the South-East Côte d'Ivoire at about $116 \mathrm{Km}$ far from Abidjan. It is situated between latitudes $5^{\circ} 15 \mathrm{~N}-6^{\circ} 15 \mathrm{~N}$ and longitudes $2^{\circ} 40 \mathrm{~W}-3^{\circ} 25 \mathrm{~W}$ (Figure 1). It belongs to the South-Comoe region and covers a surface of about $4563 \mathrm{Km}^{2}$ (Dibi, 2008). Its southern border is the prefecture of Adiake, while at western part we have the sub-prefectures of Bonoua and Alepe; then in the North raises up the Department of Abengourou and at the East stands up Ghana country. The study area covers the sub-prefectures of Aboisso, Ayame, Bianouan and Maféré. The dams of Ayame I and II also are concerned with this study.

The topography of Aboisso is monotonous as a whole. We have a hilly landscape relatively less high.

It is made of flattening faces with mean altitude varying between 150 and 200 m (Keita, 1999). In Aboisso and its surroundings we can find small trays with irregular borders, low altitudes measuring between 40 to $60 \mathrm{~m}$ (Figure 2) and

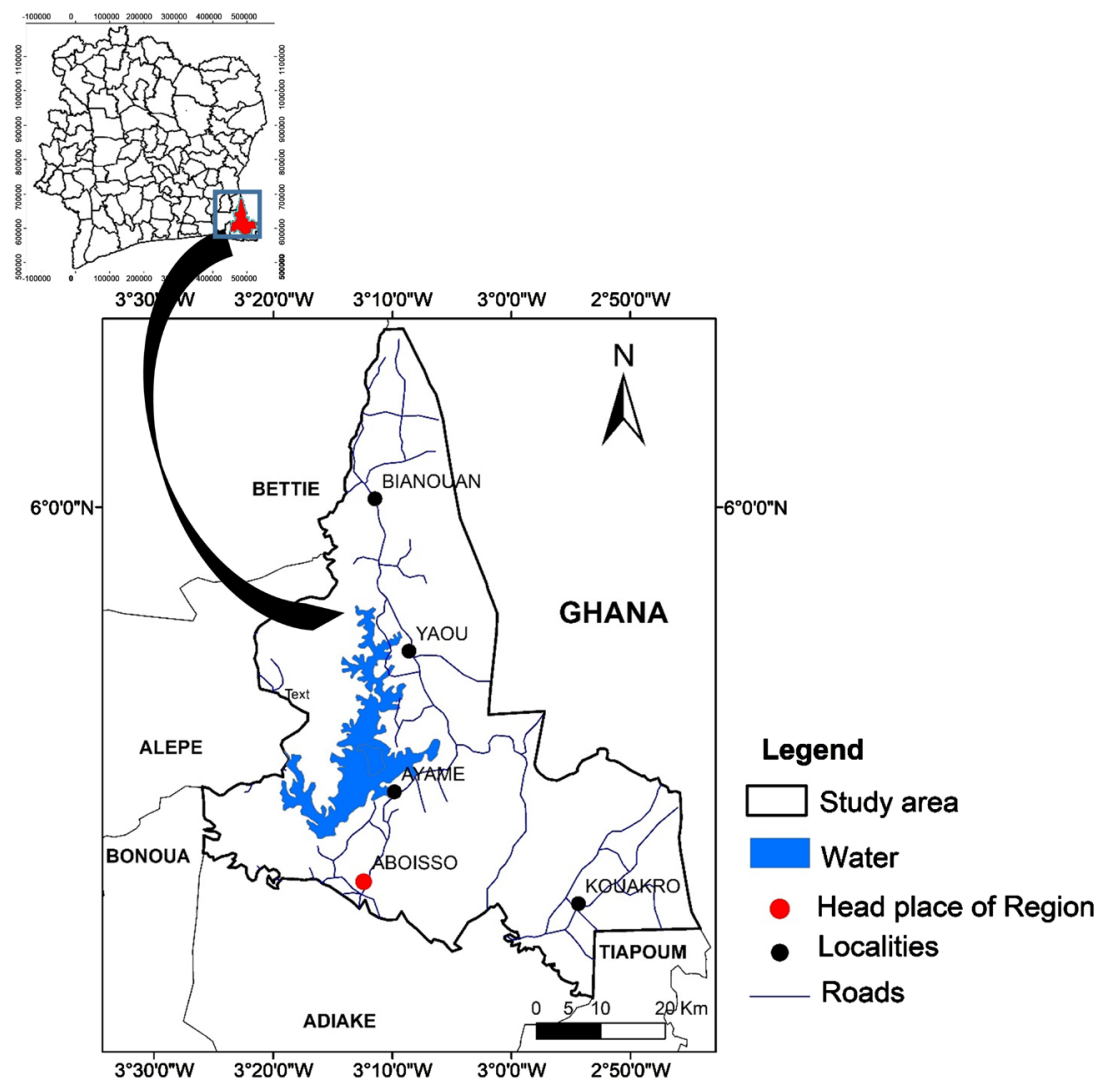

Figure 1. Presentation of the study area. 


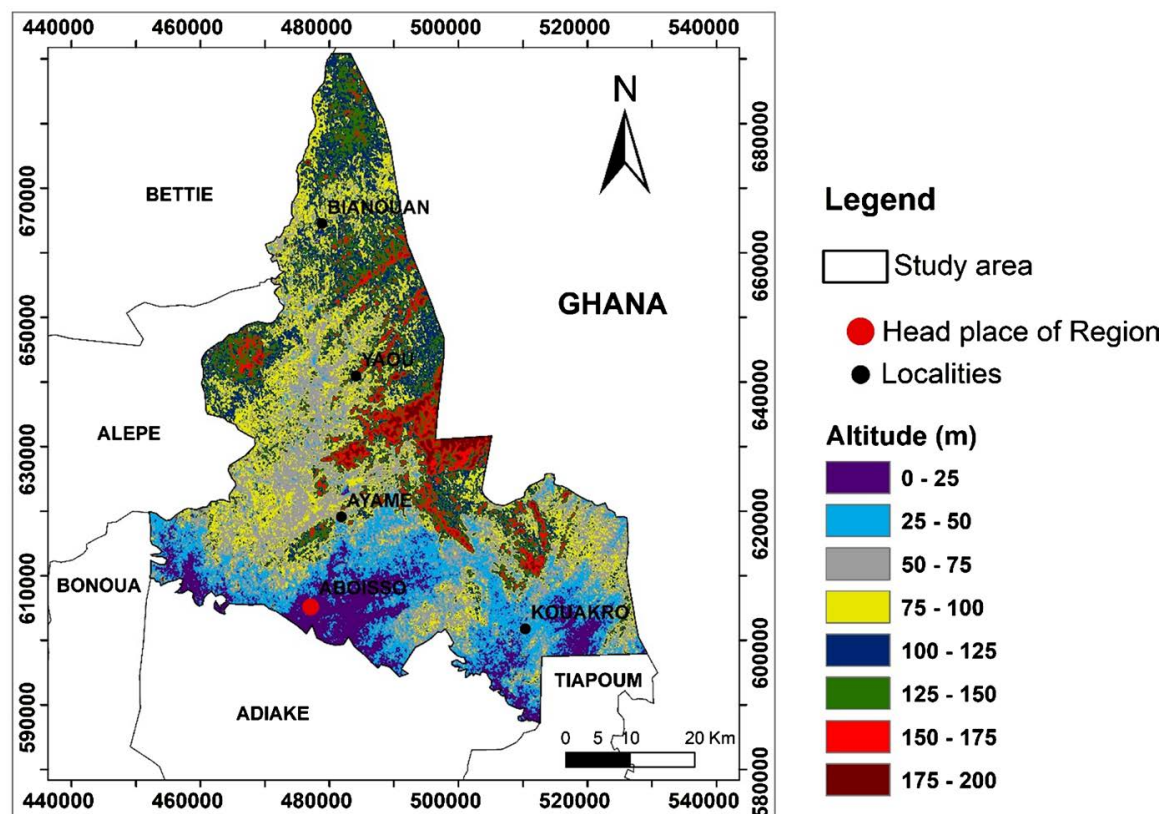

Figure 2. Map of the Altitude Numerical Model (ANM) of the Department of Aboisso.

separated by steep slope valleys (Delor et al., 1992; Keita, 1999).

The Department of Aboisso is a well-watered place with annual mean rainfall estimated at about $2000 \mathrm{~mm}$ for the period 1970 to 2015. Properly to the South Ivorian forest area, it is characterized by two rainy seasons (LRS: April to July and SRS: September to November) and two dry seasons (LDS: December to March and SDS: July to August).

From 1970 to 2015 the monthly mean temperature swan between $24.4^{\circ} \mathrm{C}$ and $28^{\circ} \mathrm{C}$. They were characterized by the four seasons with relative monthly mean moisture varying from $78 \%$ and $87 \%$ exhibiting a great sea influence in that area.

The vegetation of the Department of Aboisso changes from cleared forest on the littoral to dense evergreen forest inside the continent (Géomines, 1982).

It is built of dense forest with fulfilled of plantations of coffee-trees, cocoa-trees, palm oil-trees and some thorny shrubs, lianas and palm-trees. The outcrop zones are cover with short herbs. The other plant formations are hydromorphic formations and coastal savannahs or savannahs included. The hydromorphic formations are composed of swamp forests and mangrove woods (Dibi, 2008).

Agriculture is the main economic activity in the region and concerns more than $75 \%$ of the area (Moussa, 2006). In addition to cultivations mentioned above, many kinds of crops are developed especially rubber-trees, pineapples, coconut-trees etc. This area is also favorable for the development of food crops (plantain banana, cassava, taro, rice, etc.).

Nearby this sector of activity, grows the practice of fishing considered before as a secondary occupation by the most local people (Berron, 1979). The whole population of Aboisso is estimated at about 307852 inhabitants, meaning about $67 \mathrm{hbts} / \mathrm{km}^{2}$, with an urbanization rate of $30.1 \%$ (INS, 2014). 
The Department of Aboisso is drained by the main stream called "the Bia" flowing from the North to the South. However, it is watered with numerous rivers which are tributaries of "the Bia ", "the Tanoe" and "the Comoe".

The soils of the Department of Aboisso belong to the group of ferralitic soils, which are strongly leached because of higher rainfall covering almost all the study area. However, in the North appear shreds of ferralitic soils partially leached. At the Eastern part of Ayame's lakes, exists a cuirass of bauxite in sharpe of intrusion. These cuirasses also exist at the lower bases of lakes and streams. There are mineral and hydromorphic soils, hydromorphic gley and pseudogley soils (Perraud et De la Souchère, 1971).

There are three great entities characterizing the geology of the Department of Aboisso: shale, granite and a low layer of sedimentary formations.

In the Department of Aboisso, the lack of drillings added to a frequent breakdown of pumps encourage the most people to exploit the laterite aquifers in households (Dibi, 2008). Many watering places particularly wells exist because of these aquifers.

As for aquifers of the sedimentary basin, they are rarely exploited because the most drillings built there are feed from the sub base (Dibi, 2008).

\section{Material and Method}

\subsection{Material and Data}

This study needed to set up a database from the cartographic and climatic data. Data used are as follow:

- A landsat 7 picture of the scene 195-056 ETM+ of January $4^{\text {th }}, 2013$ used for the cartography of the parameter "land use";

- The pedological sketch of Côte d'Ivoire, sheet South-East at the scale 1/500,000 (Perraud et De la Souchère, 1971) to map land types;

- The Altitude Numerical Model (ANM) of resolution $30 \mathrm{~m}$ for the region of Sud-Comoé coming from SRTM picture, year 2000, for slope maps and drainage density;

- the alteration thickness data from the data sheets of the Abidjan Biétry village hydraulic antenna and the works of (Dibi, 2008) for the realization of the alteration thickness map;

- induced permeability data from the results of (Dibi, 2008), data sheets for the realization of the induced permeability map.

All of this data was processed by GIS software, Arcgis (10.5) and Envi image processing (5.3).

\subsection{Methodology Approach}

The methodology used in the case of this study is synthesized into four essential steps: 1) the identification of parameters allowing infiltration; 2 ) the cartography and reclassification of parameters; 3 ) the determination of weights of parameters by the method AHP of Saaty (1980) and 4) the setting up of the recharge's map 
of the Department of Aboisso. This approach was adopted by many authors especially Oularé et al., (2014); Edoukou et al., (2016); Aké et al., (2018).

\subsubsection{Identification of Parameters Allowing Infiltration}

The works of Haouchine et al., (2010); Oularé et al., (2014); Koffi (2016); Aké et al., (2018) show that the main factors governing the recharge of the aquifers at a regional scale are: the land types, the land use, the geology, the slope and the density of drainage. These are various parameters relating to the characteristics to the environment. Other authors, such as Saley, (2003); Koudou et al., (2013) include the fracturing map, induced permeability map and alteration thickness map, adapted for basement areas.

According to Michèle et al., (2011), the choice of parameters should be based on three specific criteria: 1 ) the influence of the parameter on the recharge of the underground; 2) the use of the parameter in previous studies relating to the recharge of an underground and 3) the availability of the parameter in the national cartographic database.

With regard of conditions of this study carried out in part of the base of the aquifers from the Department of Aboisso, the parameters used are: land use, soil types, slope, drainage density, induced permeability and alteration thickness. These two last parameters are judged relevant and more appropriate for this kind of area than expelled geological formations.

\subsubsection{Cartography of Parameters and Reclassification}

\section{1) Land use}

The map of land use was performed from the reclassification of a LANDSAT 7 picture of the scene 195-056 of January $4^{\text {th }}, 2013$. The reclassification started with a visual analysis of the several calculated indexes of remote sensing (NDVI, WI and $\mathrm{BI}$ ) and with the colored compositions (main components analysis (MCA)). It concerns the Landsat 7; 7, 5 and 2 bands. On the basis of this last ones, five classes of land use have been discriminated.

It's about dense forest islands; mosaic forest-cultivations, industrial crops; bare grounds, urban zones and water (Figure 3). Next, was done on the ground, the validation of the nomenclature of some suggested classes.

Data collected on the ground allowed the understanding of spectral signature of kinds of land use for making a tutorial classification of the picture.

The algorithm of classification supervised by maximum of likelihood was chosen to classify pictures. This algorithm is so used for supervised classification in the domain of land use (Bonn \& Rochon, 1992). The numerical processing (tutorial classification) was evaluated by elaboration and the analysis of the confusion matrix. It helped to appreciate de validity of the classification done. This statistical report performed on the basis of plots control (visited plots, those which didn't serve for essay) helps to evaluate the capacity of satellite pictures, for discriminating several classes of selected vegetation. Nextly, the results of the confusion matrix are compared with structural parameters of the selected ground 
vegetation. Once the classification was accepted, the median filter $3 \times 3$ was combined to the classified picture to cancel isolated pixels and make profiles of several classes obtained soft.

\section{2) Soil types}

The setting up of the pedological map or the soil type map was performed by digitation of the pedological map of the South-East Côte d'Ivoire (Perraud et De La Souchère, 1971) at the scale 1/500,000. From this map (Figure 4), four types of soils were obtained for the studied area: the ferrasols, the petroplinthic ferrasols, the gleysols and the sommitic cuirasses.

The infiltration capacity of a soil depends essentially on its granulometry (clay, silt, sand etc.), and therefore its permeability. Moreover, compaction of the

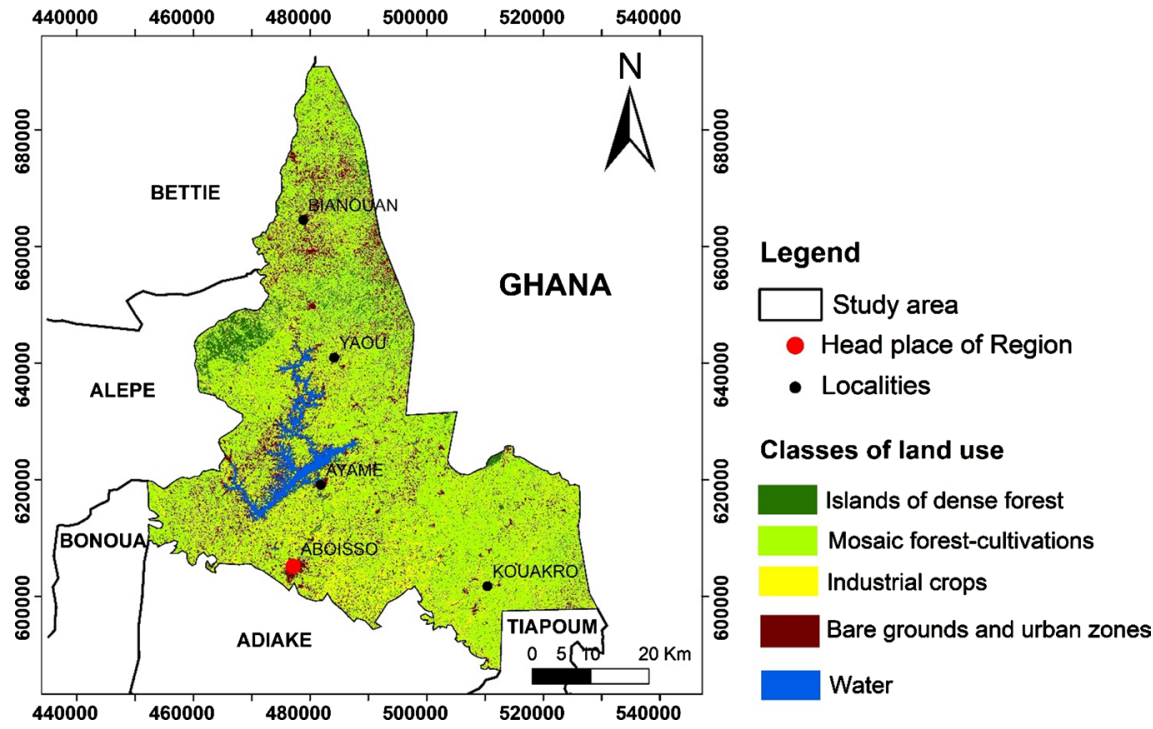

Figure 3. Map of the land use of the Department of Aboisso.

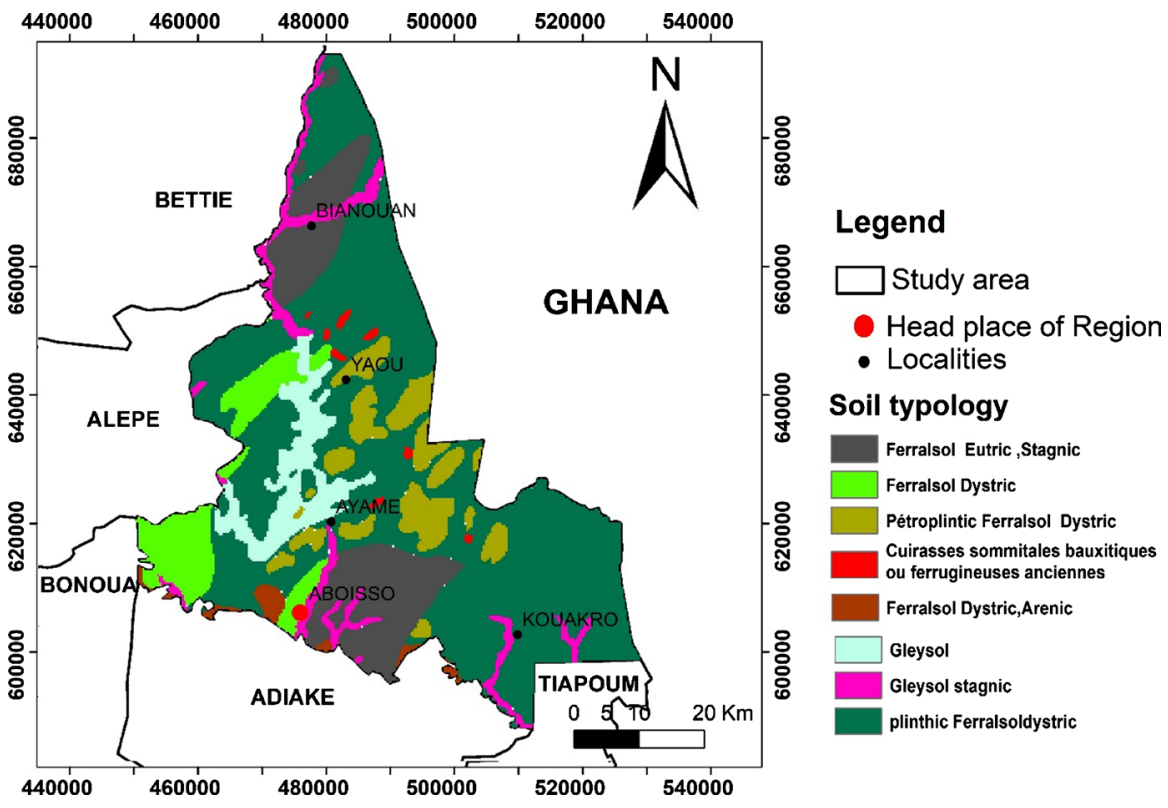

Figure 4. Map of the soil of the Department of Aboisso. 
soil surface due to raindrops impact (beating) or other effects (thermal and anthropogenic) can result in degradation of the soil surface layer structure and the formation of dense and impermeable crust at a certain depth (Haouchine et al., 2010).

\section{3) Slopes}

The slopes map (Figure 5) was performed from the ANM of Côte d'Ivoire that is coming from SRTM satellite pictures of $30 \mathrm{~m}$ resolution. From that one, the slope (S) parameter was mapped using "Slope" ArcGis tool.

Four slope classes according to their capacity to facilitate infiltrations were specified as follow: $\left(\alpha<5^{\circ}, 5<\alpha<10^{\circ}, 10^{\circ}<\alpha<15^{\circ}\right.$, et $\left.\alpha>15^{\circ}\right)$. The Department of Aboisso is dominated with low slopes inferior to $5^{\circ}$.

\section{4) Drainage density}

The map of drainage density (Figure 6) was performed from the hydrographic network of the Department of Aboisso. This last was obtained from the ANM map through "kernel-density" tool of ArcGis software. Four classes of the drainage density $(0.085<\mathrm{Dd}<0.363 ; 0.363<\mathrm{Dd}<0.519 ; 0.519<\mathrm{Dd}<0.682 ; 0.682$ $<\mathrm{Dd}<1.128)$ were obtained with high density around streams and crossbreeding tributaries. The drainage density grows smaller the more we move farther from the streams.

\section{5) Induced permeability}

The estimation of induced permeabilities by the breaks, is an approach facilitating modelization of flow in cristallin area and cracked cristallophyllian. The map of induced permeability (Figure 7) was deduced from the works of Dibi (2008). Four classes of induced permeability $\left(1.89-3.43 \times 10^{-6} \mathrm{~m} / \mathrm{s} ; 3.43-4.97 \times\right.$ $10^{-6} \mathrm{~m} / \mathrm{s} ; 4.97-6.5 \times 10^{-6} \mathrm{~m} / \mathrm{s} ; 6.51-8.06 \times 10^{-6} \mathrm{~m} / \mathrm{s}$ ) were obtained according to their percolation capacity.

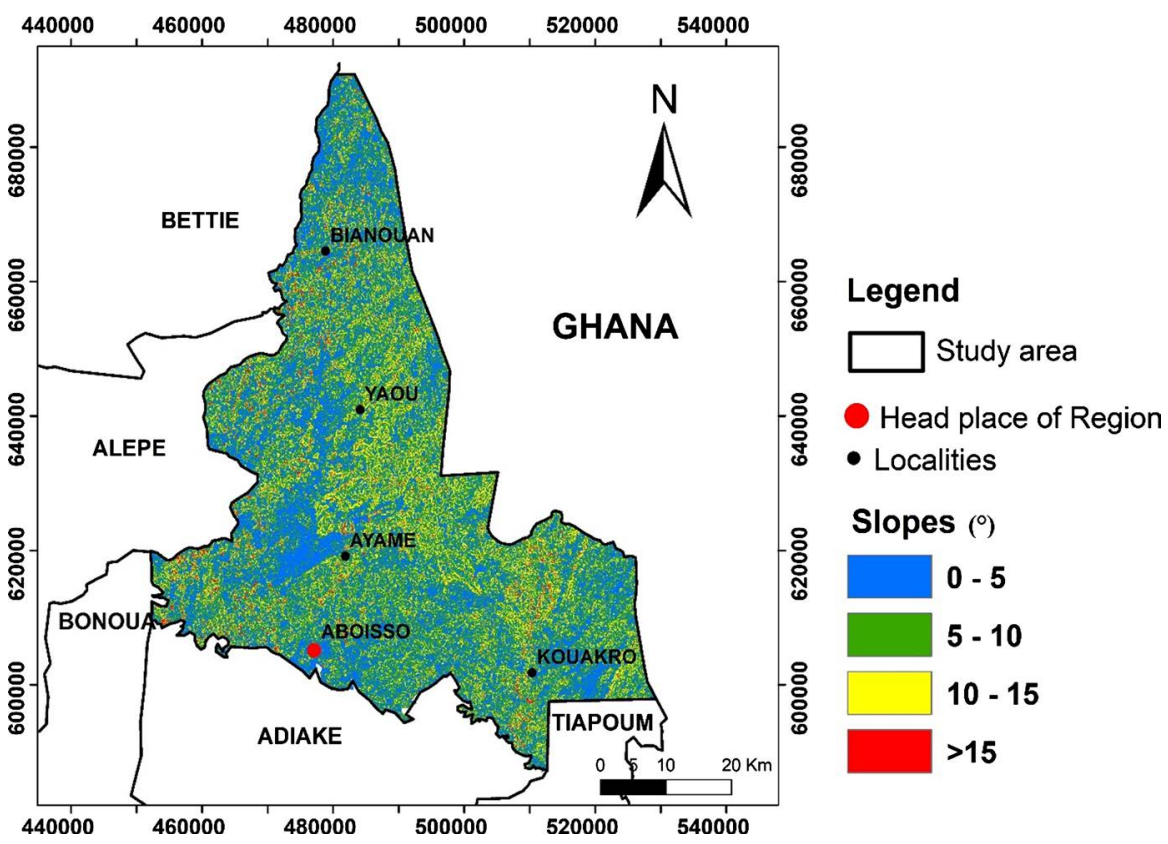

Figure 5. Map of slopes of the Department of Aboisso. 


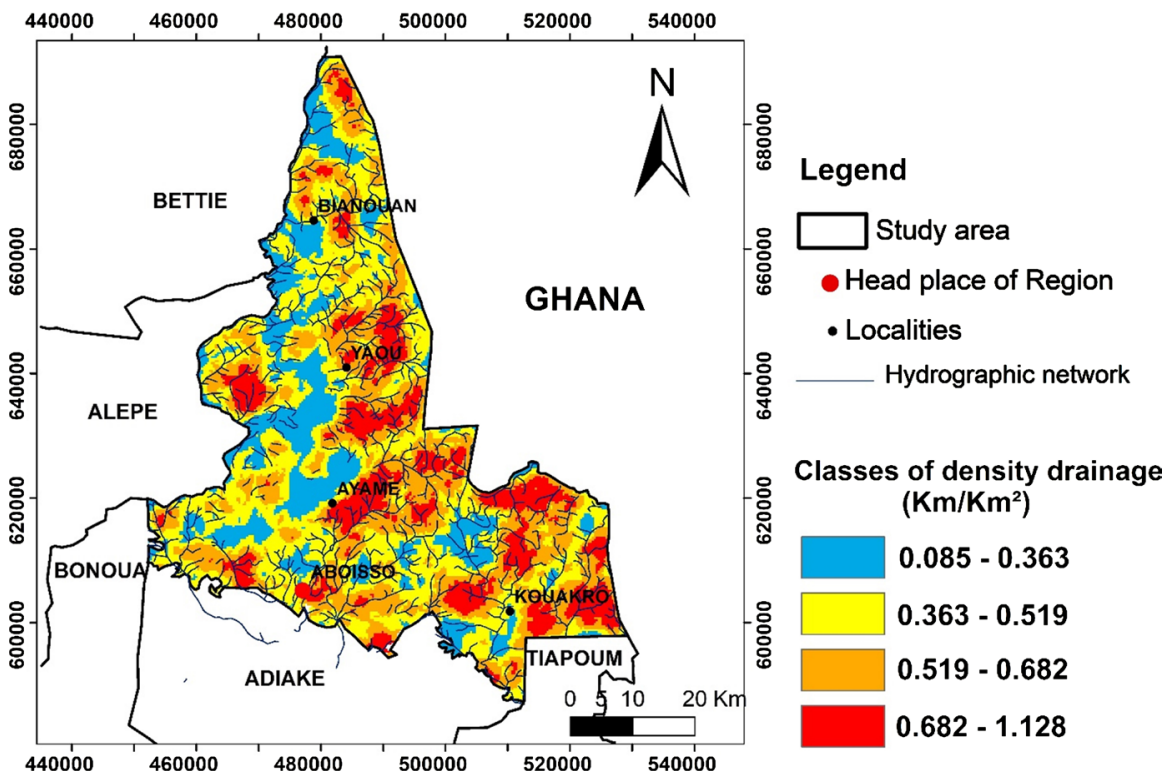

Figure 6. Map of density of drainage of the Department of Aboisso.

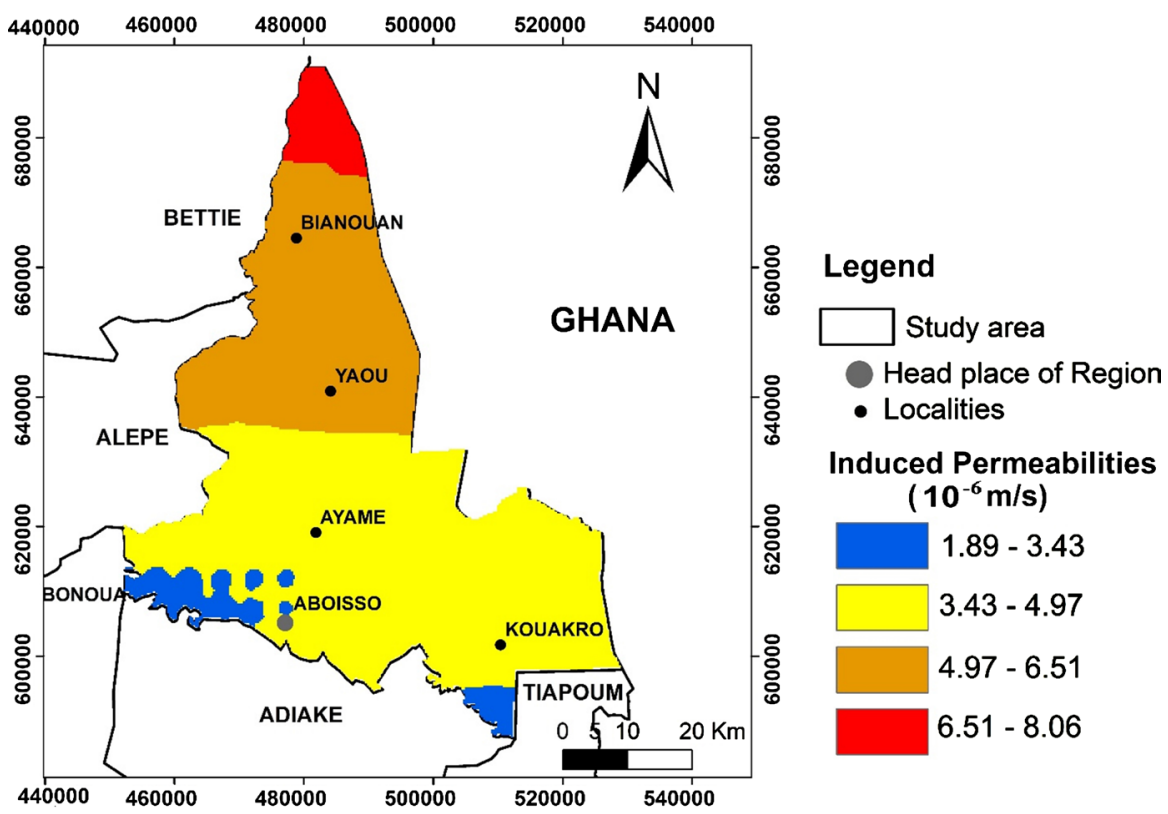

Figure 7. Map of the induced permeabilities of the Department of Aboisso (Dibi, 2008 modified).

\section{6) Alteration thickness}

It was realized from technical sheets of the villager hydraulic antenna of Abidjan Bietry and regarding the works of Dibi (2008). These data process helped setting up the depth's map of the study area. Five classes of alteration thickness were obtained $(3-10 \mathrm{~m} ; 10-30 \mathrm{~m} ; 30-50 \mathrm{~m} ; 50-70 \mathrm{~m} ; 70-85 \mathrm{~m})$ relating to their depth.

\section{7) Reclassification of parameters}

The reclassification of parameters consists in to assign scores to different classes of parameters chosen for the cartography of the recharge. That method in 
based on the application of scores to several classes of parameters according to their infiltration's level with consideration of intervals. The map of potential recharge areas is obtained by combining the maps of the various parameters or reclassified criteria involved in the determination of the recharge zones.

It means that to evaluate homogenously the scores of the different parameters from the scores scale with regard of infiltration suggested before by Haouchine et al., (2010). In previous works of Koffi (2016); Aké et al., (2018) also used it before (Table 1). That scale was realized on the basis of variations ranges of the parameters.

Table 1. Scores assigned to the parameters of the aquifers recharge of the Department of Aboisso.

\begin{tabular}{|c|c|c|c|}
\hline Parameters & Classes & Recharge levels & Scores \\
\hline \multirow[t]{4}{*}{ Land use } & Mosaic forest cultivations & Very high & 10 \\
\hline & Dense forest islands & high & 8 \\
\hline & Industrial crops & medium & 6 \\
\hline & Bare grounds, urban zones and water & Low & 2 \\
\hline \multirow[t]{4}{*}{ Soil types } & Ferrasols & High & 8 \\
\hline & Petroplinthicferralsol & Medium & 6 \\
\hline & Gleysols & Medium to low & 4 \\
\hline & Sommitic cuirasses & Low & 2 \\
\hline \multirow[t]{5}{*}{ Slopes $(\%)$} & Classes of slopes & & \\
\hline & $0-5 \%$ & High & 8 \\
\hline & $5 \%-10 \%$ & High to medium & 6 \\
\hline & $10 \%-15 \%$ & Low to medium & 4 \\
\hline & $\alpha>15 \%$ & Low & 2 \\
\hline \multirow[t]{5}{*}{ Drainage density $\left(\mathrm{Km} / \mathrm{km}^{2}\right)$} & Classes of the drainage density & & \\
\hline & $0<\mathrm{Dd}<0.332$ & Very high & 10 \\
\hline & $0.332<\mathrm{Dd}<0.491$ & High & 8 \\
\hline & $0.491<\mathrm{Dd}<0.659$ & Low & 5 \\
\hline & $0.659<\mathrm{Dd}<1.128$ & Very low & 2 \\
\hline \multirow[t]{5}{*}{ Induced permeability $\left(10^{-6} \mathrm{~m} / \mathrm{s}\right)$} & Classes of the induced permeability & & \\
\hline & $6.51-8.06$ & Very high & 10 \\
\hline & $4.97-6.51$ & High & 8 \\
\hline & $3.43-4.97$ & Medium & 5 \\
\hline & $1.89-3.43$ & Low & 2 \\
\hline \multirow[t]{6}{*}{ Alteration thickness (m) } & Classes of alteration thickness & & \\
\hline & $3-10$ & Very high & 10 \\
\hline & $10-30$ & High & 8 \\
\hline & $30-50$ & Medium & 5 \\
\hline & $50-70$ & Low & 3.5 \\
\hline & $70-85$ & Very low & 1 \\
\hline
\end{tabular}




\subsubsection{Determination of Parameters Weights through the Method of Multicriteria Analysis (AHP) of Saaty}

The AHP method is a pairwise comparison method used for objective determination of criteria weights. Contrary to the weighting technical based on a random choice of weights, that proposed by Saaty (1977) is a simple method consolidated with mathematical calculations producing standardized weighting coefficients, which combination result is one.

Similary works in Côte d'Ivoire used it: Jourda et al., (2007); Kouame (2007); Koffi (2016); Aké et al., (2018) and gave satisfying results.

This method allows in specifical way to make efficient decisions about complex problems by simplifying and speeding up decision-making processes Saaty (1980).

Using coupled-comparison matrix produced on Saaty's scale, the calculation of specific vectors and weighting coefficients becomes easy. So, that method was chosen in the case of this study.

Opinions of some experts of various fields were collected to make qualitative judgements basing on a scale of 1 to 10 of Haouchine et al., (2010) for the parameters influencing infiltration (Table 2).

A comparison of Experts' opinions relating to the approach of Haouchine et al., (2010), on the determination of recharge zones, was done by self-adaptation to the Aboisso Department's realities. This process was used by Aké et al., (2018) for the underground of Bonoua too. It helped to estimate the relative importance of the parameters each other. That process led to a coupled-comparison of infiltration parameters of the Department of Aboisso, for which weights are given in Table 3.

So, the ranking of parameters according to their importance for the recharges of aquifers of the Department of Aboisso is set up as follow: $\mathrm{LU} \gg>\mathrm{S} \gg \mathrm{AD}>$ $\mathrm{S}>\mathrm{IP}>\mathrm{Dd}$. The coupled- comparison of parameters led to a matrix mentioned in Table 4.

The element of the left column is successively compared with each element of the matrice's row. If the comparison is not favourable to the element of the left column regarding the element of the row, the appreciation is expressed throughout the fraction. On the opposite case, we use an entire number.

Following binaries comparisons, a checking of the coherence of judgements was necessary by setting up priorities. In fact, the setting up of priorities allows

Table 2. Scale of several parameters opposite to infiltration (Haouchine et al., 2010).

\begin{tabular}{cccccccc}
\hline Classe & Very high & High & High to medium & Medium & Medium to low & Low & Very low \\
\hline Scores & 10 & 8 & 6.5 & 5 & 3.5 & 2 & 1 \\
\hline
\end{tabular}

Table 3. Weights assigned to several infiltration parameters of the Department of Aboisso.

\begin{tabular}{ccccccc}
\hline Parameters & $\begin{array}{c}\text { Land use } \\
(\mathrm{LU})\end{array}$ & $\begin{array}{c}\text { Land types } \\
(\mathrm{LT})\end{array}$ & $\begin{array}{c}\text { Ateration depth } \\
(\mathrm{AD})\end{array}$ & $\begin{array}{c}\text { Slope } \\
(\mathrm{S})\end{array}$ & $\begin{array}{c}\text { Induced-permeability } \\
(\mathrm{IP})\end{array}$ & $\begin{array}{c}\text { Density of } \\
\text { drainage (Dd) }\end{array}$ \\
\hline Weights & 9 & 7.5 & 7 & 6.5 & 6 & 4 \\
\hline
\end{tabular}


to synthetize our appreciations from a mathematical view in order to check their coherences (Anoh et al., 2012).

The variation of the coherence of judgements allowing the building of the hierarchical matrix needs the calculation of the coherence ratio as follow:

$$
R c=\frac{I c}{I a}
$$

Ia is the random index equal to 1.24 in this study because the method is used with six criteria (Table 5).

Ic is the index of coherence and is expressed by the relation noted 2:

$$
I c=\frac{K \max -k}{k-1}
$$

( $\Lambda$ max: average of rational priorities, $k$. number of parameters compared). In our case, $I c=0.06$ (Table 6).

The ratio of coherence can be explained as the probability that the matrix can be completed in randomly. The method AHP doesn't require that the judgements be coherent not transitive. On the contrary (Saaty, 1980) defined the ratio

Table 4. Matrix deriving from the comparison of the several parameters (Original Matrix).

\begin{tabular}{cccccccccc}
\hline & $\mathrm{LU}$ & $\mathrm{S}$ & $\mathrm{AD}$ & $\mathrm{S}$ & $\mathrm{IP}$ & $\mathrm{Dd}$ & Specific vector & Sum of row & $\mathrm{Cp}$ \\
\hline $\mathrm{LU}$ & 1 & 2 & 3 & 4 & 5 & 7 & 3.07 & 22 & 0.38 \\
$\mathrm{~S}$ & $1 / 2$ & 1 & 2 & 3 & 3 & 7 & 1.99 & 16.45 & 0.24 \\
$\mathrm{AD}$ & $1 / 3$ & $1 / 2$ & 1 & 2 & 3 & 5 & 1.31 & 11.83 & 0.16 \\
$\mathrm{~S}$ & $1 / 4$ & $1 / 3$ & $1 / 2$ & 1 & 2 & 5 & 0.86 & 9.03 & 0.11 \\
$\mathrm{IP}$ & $1 / 5$ & $1 / 3$ & $1 / 3$ & $1 / 2$ & 1 & 3 & 0.57 & 5.37 & 0.07 \\
$\mathrm{Dd}$ & $1 / 7$ & $1 / 5$ & $1 / 5$ & $1 / 3$ & $1 / 3$ & 1 & 0.29 & 2.21 & 0.04 \\
$\mathrm{Sum}$ & & & & & & & 8.09 & 66.89 & 1 \\
\hline
\end{tabular}

Table 5. Random index value (Ri) of a matrix of the same length (Saaty, 1980).

\begin{tabular}{ccccccccccc}
\hline Number of criteria & 2 & 3 & 4 & 5 & 6 & 7 & 8 & 9 & 10 & 1 \\
\hline $\mathrm{Ri}$ & 0 & 0.58 & 0.90 & 1.12 & 1.24 & 1.32 & 1.41 & 1.45 & 1.49 & 1.51 \\
\hline
\end{tabular}

\begin{tabular}{|c|c|c|c|c|c|c|c|c|c|c|c|c|}
\hline & $\mathrm{LU}$ & S & $\mathrm{AD}$ & S & IP & $\mathrm{Dd}$ & Sum of row & $\mathrm{E}$ & $\mathrm{C}$ & Max & Ic & $\mathrm{Rc}$ \\
\hline LU & 0.38 & 0.49 & 0.48 & 0.42 & 0.35 & 0.25 & 2.38 & 6.29 & 0.40 & & & \\
\hline$S$ & 0.19 & 0.24 & 0.32 & 0.32 & 0.21 & 0.25 & 1.54 & 6.26 & 0.26 & & & \\
\hline $\mathrm{AD}$ & 0.13 & 0.12 & 0.16 & 0.21 & 0.21 & 0.18 & 1.01 & 6.26 & 0.17 & & & \\
\hline S & 0.09 & 0.08 & 0.08 & 0.11 & 0.14 & 0.18 & 0.68 & 6.44 & 0.11 & & & \\
\hline IP & 0.07 & 0.08 & 0.05 & 0.05 & 0.07 & 0.11 & 0.44 & 6.29 & 0.07 & & & \\
\hline $\mathrm{Dd}$ & 0.05 & 0.05 & 0.03 & 0.03 & 0.02 & 0.03 & 0.23 & 6.43 & 0.04 & & & \\
\hline Sum & 0.92 & 1.07 & 1.14 & 1.15 & 1.01 & 1 & 6.30 & 37.97 & 1.05 & 6.33 & 0.06 & 0.05 \\
\hline
\end{tabular}

Table 6. Standardized matrix $[\mathrm{A}]$. 
value of coherence. In the case of a coherence ratio over $10 \%$, appreciations can be reviewed. In the case of this study, $R c=5 \%$, therefore the judgements are consistent.

\subsubsection{Cartography of the Potential Aquifers Recharge Areas of the Aboisso Department}

The mapping of the potential aquifers recharge areas of the Aboisso department was performed by combination of all parametric maps set up in raster file throughout GIS.

The calculation method used in GIS for the combination of maps is the operational approach of Roy's synthesis unique criterion (Garouni \& Merzouk, 2006). The principle consists of adding the different layers according to their importance. The probability that the recharge inside a zone be high will therefore be related to the values of the classes of the parameters that intersect according to Equation (3).

So, the calculation of the recharge index $(R i)$ performed with GIS is the following:

$$
\begin{aligned}
R i= & 0.38 \times[L U]+0.24 \times[S]+0.16 \times[A D] \\
& +0.11 \times[S]+0.07 \times[I P]+0.03 \times[D d]
\end{aligned}
$$

$R i$ corresponds to the sum of calculated weighted scores for each pixel of raster from the score of the six parameters.

Aller et al., (1987) set up a method (Equation (3)) to move from indexes to several vulnerability levels. That method was used in the case of this study to move from the recharge indexes $(R i)$ to different recharge level classes in the study area.

$$
\operatorname{Irp}=\frac{P(\text { Irmax }- \text { Irmin })}{100}+\text { Irmin }
$$

Irp is the recharge index in percentage; $P$ corresponds to a percentage class. Irmax is the optimal recharge index and Irmin is the minimal recharge index.

The recharge indexes obtained were expressed as percentage based on the breakdown of the values in the works of Jourda et al., (2007); Aké (2010), Koffi (2016); Aké et al., (2018). These indexes allowed the determination of the recharge level classes of the study area.

The determination of the recharge index of these intervals in the Aboisso department makes strong the works from Koffi (2016); Aké et al., (2018). That method conducted to five classes of potential recharge zones.

As the weighting coefficient is fixed, the minimal index recharge that a parameter could have, in the case of this study, is 2.67 and the optimal index is 8.85 . Substituting the several values, the Equation (4) is now:

$$
\operatorname{Irp}=\frac{8.85-2.67}{100}+2.67
$$

Table 7 resumes the total of classes and recharge indexes of the potential zones to infiltration of the Aboisso Department. 
Table 7. Classes and indexes of favorable zones to infiltration of the Department of Aboisso.

\begin{tabular}{ccc}
\hline Classes of recharge & Recharge index (Ir) standardise (\%) & $\mathrm{Ri}$ \\
\hline Bad & $0-30$ & $2.67-5.74$ \\
Mediocre & $30-45$ & $5.74-7.03$ \\
Medium & $45-60$ & $7.03-8.01$ \\
Good & $60-75$ & $8.01-8.56$ \\
Very good & $75-100$ & $8.56-8.85$ \\
\hline
\end{tabular}

\section{Results and Discussion}

\subsection{Map of the Potential Recharge Areas of the Aquifers of the Department of Aboisso}

The index values of the recharge obtained in the area study range between 2.83 and 8.83 (Figure 8$)$. The highest recharge indexes $(6.76-8.85)$ are located in the far North, in the Center (Yaou), in the South-East (Kouakro) and in the West. We notice a dominance of indexes ranging between 6.76 and 7.71 in the South, in the South-East and in the South-West of the study area. The lowest index values of the recharge are found in the localities of Aboisso, Ayame and Bianouan.

The reclassification of the aquifer recharge index map of the study area provided a map of potential recharge areas with five classes (Figure 9).

\section{Bad}

It represents $20 \%$ of the study area. We meet this class in the localities of $\mathrm{Ab}$ oisso, Ayame and Bianouan, where we note the presence of high thickness of alteration and urban area. We also find it in the streams characterized by gleysols favoring a bad index of the recharge.

\section{Mediocre}

We find this class anywhere else in the study area, but a little more marked in

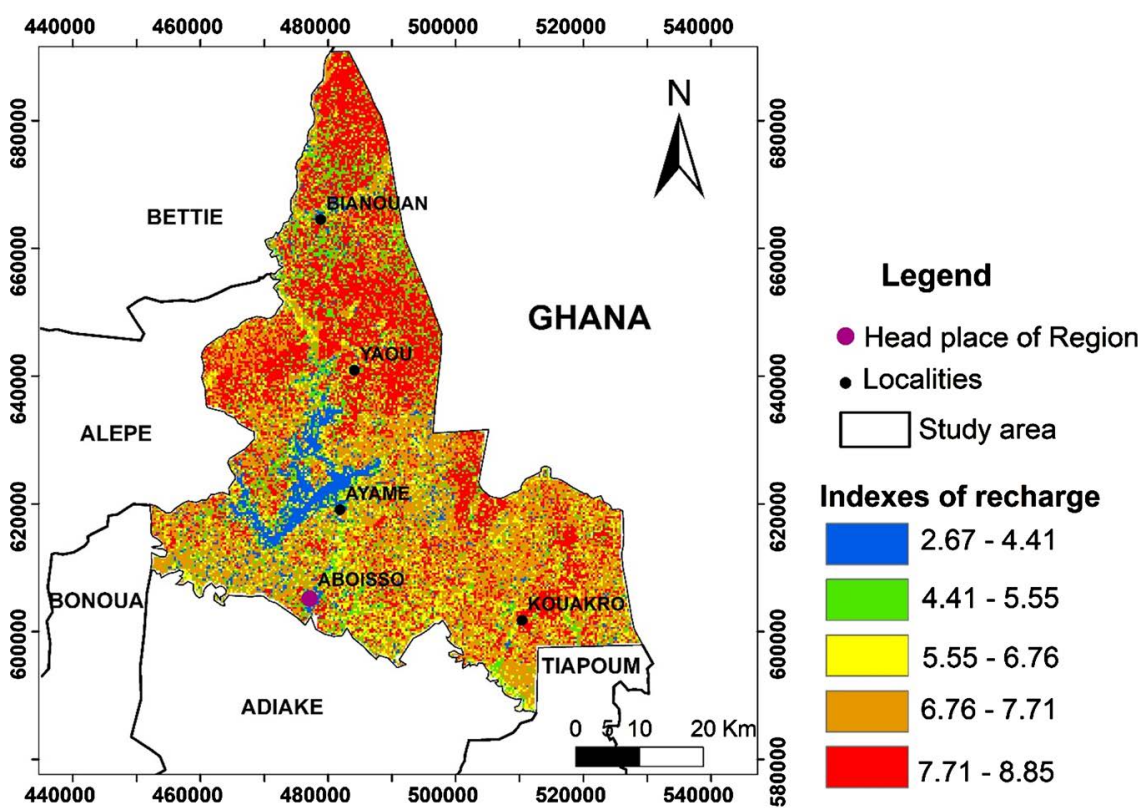

Figure 8. Map of the recharge indexes of the aquifers of the Department of Aboisso. 


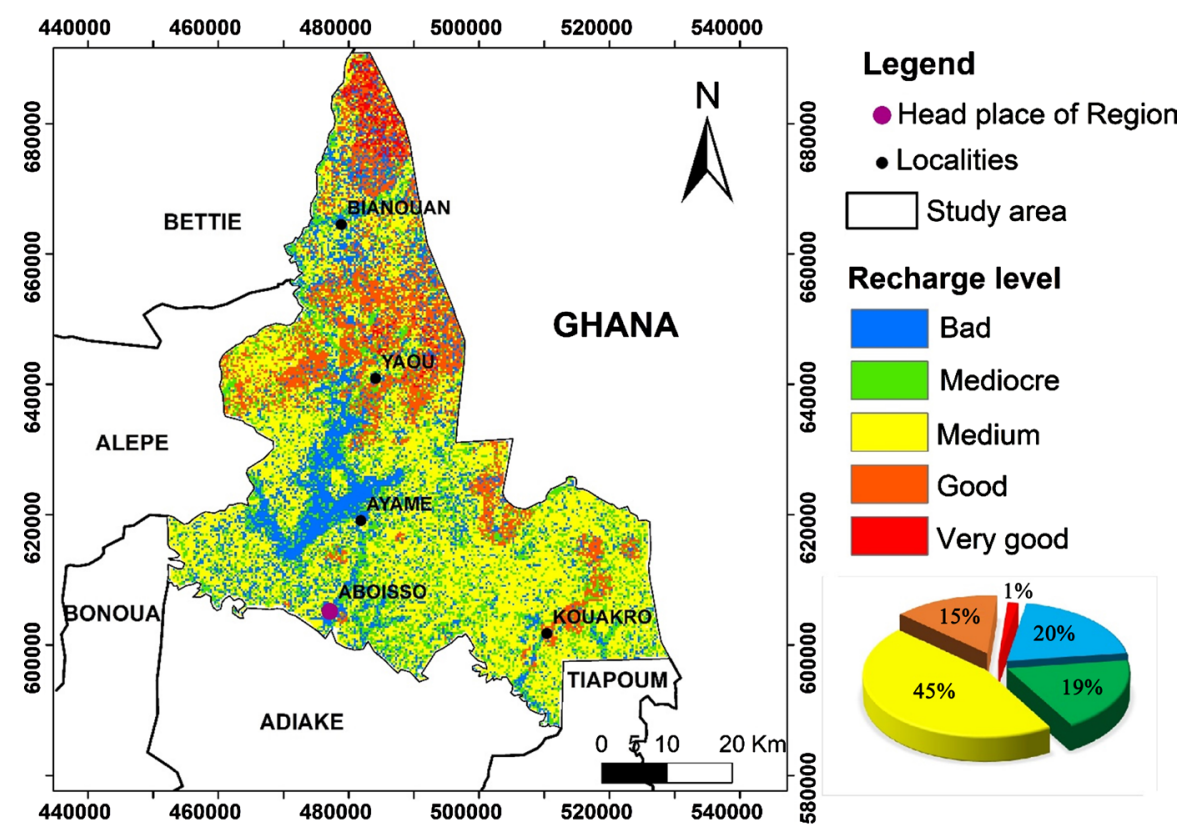

Figure 9. Map of potential recharge areas of the aquifers of the Department of Aboisso.

the South and North of the department. The low level of recharge is due to the presence of urban areas and high drainage, which favors runoff at the expense infiltration. It takes $19 \%$ of the study area.

\section{Medium}

This class takes place in almost totality of the study area. It is more accentuated in the South, South-West, South-East, Center and a little part in the North (Bianouan). This medium level should be the consequence of a medium induced permeability recorded for a medium thickness alteration ( 30 to $50 \mathrm{~m}$ ) where the slope is low. It represents $45 \%$ of the study area.

\section{Good}

This class represents $15 \%$ of the study area. It is located in the Center (Yaou and its surroundings), in the South-East and in the North of the study area. This class is characterized by areas where, several parameters taken into account together promote good infiltration. Indeed, this class is marked by areas where there is an average drainage, low slopes and the presence of mosaic forest-crops.

\section{Very good}

This class represents the ideal area for an important infiltration of water in the Department of Aboisso and takes only $1 \%$ of the surface.

We find this class in the North and in little part of the Center. In these areas, the slope is low with induced permeability that provides information on fracture intensity that serves as a channel for aquifer recharge.

\subsection{Discussion}

\section{Cartography of the potential recharge areas}

The synthesis map of favorable areas to recharge aquifers is for the user a tool for decision support. It's a useful tool for better management of water resource 
in the Department of Aboisso.

Spatialization of recharge areas by the multicriteria analysis approach is poorly addressed in the literature. That of the study area, although it is a decision-making tool, requires careful study.

The development of the map of the potential recharge zones in the middle of the basement required the taking into account of six parameters: land use, soil types, alteration thickness, slope, permeability induced (own basement) and drainage density. The integration of these parameters with GIS helped making the map of the potential recharge zones of the study area.

Remote sensing and GIS have been shown to be effective in identifying potential aquifer recharge areas in many basement hydrogeological studies (Oularé et al., 2014) and in sedimentary environments (Koffi, 2016; Aké et al., 2018). These tools have also yielded satisfactory results in assessing the recharge potential of fractured aquifers in many regional hydrological studies (Salama et al., 1994; Shaban et al., 2006; Yeh et al., 2009).

That process got advantages to be cheap for studies relating to great areas extending from many hundreds of $\mathrm{Km}^{2}$ to some thousands of $\mathrm{Km}^{2}$, and this, contrary to experimental methods that are expensive for limited areas (example: isotopic, hydrochemical and hydraulic methods etc.). The map of potential recharge areas reveals five classes of infiltration level (bad, mediocre, medium, good and very good). The areas that are suitable for infiltration (medium, good and very good) are located on the low slopes $\left(0\right.$ to $\left.5^{\circ}\right)$, with a low drainage density, resting under a mosaic of forest-crops, favorable conditions for infiltration. We find these areas around the localities of Yaou, Kouakro and the North Bianouan.

Areas for which recharge is bad or mediocre are located in urban places, bare grounds and in industrial crops areas, gleysols where slope is relatively low. This is probably due to ground covering with foliage and the clay-sanded nature of gleysols. Gleysols are naturally less permeable. Although the slope is low, their higher retention capacity reduces infiltration. According to Jourda et al., (2007), weak slopes favor infiltration. These low levels of recharge are also due to a large thickness of alteration and a low permeability induced due to a small network of fractures in these areas.

This study revealed that important parameters in determining recharge include land use, soil typology and alteration thickness.

The preponderant parameter is the land use as noticed before in the works of Aké et al., (2018) about the underground of Bonoua. However, although land use is critical, it is itself conditioned by soil type (Aké et al., 2018).

The reclassification of land use map reveals a lower water infiltration in bare grounds, urbans areas and water. These areas are waterproofed because of anthropogenic actions (urbanization) with the result, a low infiltration of water at the expense of runoff.

The mean values of induced permeability noted in the study area range in the 
order of $10^{-6} \mathrm{~m} / \mathrm{s}$. These values are sensibly equal to values of the sedimentary formations permeability taking from essay data of pumping varying between $10^{-6}$ to $10^{-4} \mathrm{~m} / \mathrm{s}$ in the Southern part of that area (Dibi, 2008). The analysis of induced permeability map brings to light four classes, whose the most relevant are the medium and higher classes. The alteration thickness plays an important role for the availability of underground resources. According to Lachassagne et al., (2001), the lower recharge indexes recorded are the fact of higher alteration thickness in these areas.

These zones of higher recharge could be risk of pollution for the aquifers of the Department. Indeed, the works of Dibi (2008) have exhibited that about 60\% of the surface area is occupied with favorable areas with the implementation of water supply. However, $5 \%$ of this part remain at risk of pollution.

The implementation of methodology for the cartography of potential recharge areas of the aquifers for the Department of Aboisso can be resumed in four steps. It has encountered so much operating problems.

\section{Limits of the methodology}

- The difficulty in determining the parameters comes from the limitation of the number of parameters to be considered. According to Saaty (1980), the choice of the parameters or criteria should not exceed seven for each hierarchic level. Thus, the 6 parameters chosen through this method, have been judged as the most significant for characterizing these recharge areas. Moreover, the geological formation parameter was not retained in this study, since its implication is more felt by the induced permeability deriving from the fracturing and the alteration thickness of the boreholes of the zone.

- The subjectivity of weights and scores assigned to parameters by using AHP method of Saaty is also a problem. Values assigned to parameters sometimes overestimate or underestimate the infiltration level. The choice of class's limits, so often, operates in function to the operator's faculty of discernment and its sense of judgement (Jourda et al., 2007).

- The mapping of potential aquifer recharge areas in the Aboisso department may contain errors. In fact, in the reclassification of land use the same ratings were given for degraded forests and crops and also the same rating was assigned to all industrial crops. Yet, these different industrial cultures do not have the same influence on infiltration. In addition, the slope parameter did not change significantly over the extent of the study area.

- The map of potential aquifer recharge areas may contain a margin of error. Indeed, the criteria: thickness of alteration, induced permeability and density of drainage, were obtained by interpolation. Interpolation can bring errors when setting up parameters. It is only credible inside intervals bordered with specific data (Jourda et al., 2007).

- Some parameters such as soil type and land use can be grouped into a single factor to allow for a greater number of parameters (Douay \& Lardieg, 2010). Yet, in this study, both parameters don't have the same influence on the re- 
charge of the studied area. Furthemore, land use is determined as a preponderant factor in the determination of recharge areas by the Saaty method, as it influences the surface condition and soil structure and thus slows runoff and promotes infiltration. However, the vegetation or the land use depends on the lithology. It involves that the lithology or the soil type could be the preponderant parameter in the characterization of the recharge areas.

The map of potential recharge areas produced in this study should have been validated by infiltrometers installed in the potential recharge areas. It could also be done by following the piezometric level by setting a piezometer on the different recharge zones and see the rise of underground when it rains. Failure to observe these measures could also be limits to this work.

Although this fact, the map of the potential recharge areas we have completed remains reliable. This study remains an effective approach for mapping potential recharge areas.

\section{Conclusion}

The development, weighting and combination in a GIS of the different parameters (land use, soil types, alteration thickness, slope, induced permeability and drainage density) influencing infiltration conducted to set up the map of the potential recharge areas of the aquifers of the Department of Aboisso. This map highlights fives classes of recharge areas (bad 20\%, mediocre 19\%, medium 45\%, good $15 \%$ and very good $1 \%$ ) with medium, good and very good classes dominance covering $61 \%$ of the study area. In the case of this study, the aquifers of the Department of Aboisso are so favorable to recharge whose relevant element is the land use allowing infiltration.

These results are an excellent tool for preventing risks of pollution, and thus allow a good management of the groundwater resource in the direction of sustainable development.

This map implemented enhances knowledge relating to the hydrogeological characteristics of the Department of Aboisso. Finally, this study exhibited that remote sensing and GIS tools can contribute greatly to perform the cartography of the potential recharge areas of aquifers, which constitutes a principal factor for the management of groundwater resources.

\section{Conflicts of Interest}

The authors declare no conflicts of interest regarding the publication of this paper.

\section{References}

Ake, G. E. (2001). Evaluation des ressources en eau souterraine de la région de Bonoua (72 p.). Mémoire de DEA des Sciences de la Terre, Abidjan: Université de Cocody.

Ake, G. E. (2010). Impacts de la variabilité climatique et des pressions anthropiques sur les ressources hydriques de la région de Bonoua (Sud-Est de la Côte d'Ivoire) (200p.). Thèse de Doctorat, Abidjan: Université de Cocody. 
Ake, G. E., Kouame, K. J., Koffi, A. B., \& Jourda, J. P. (2018). Cartographie des zones potentielles de recharge de la nappe de Bonoua (sud-est de la Côte d'Ivoire). Revue des sciences de l'eau, 31, 129-144. https://doi.org/10.7202/1051696ar

Aller, L., Bennett, T., Lehr, J. H., Petty, R. J., \& Hackett, G. (1987). Drastic: A Standardized System for Evaluating Ground Water Pollution Potential Using Hydrogeologic Settings (622 p.). Ada, OK: EPA.

Anoh, K. A., Jourda, J. P., Kouame, K. J., Koua, T. J. J., Eba, A. E., \& Lazar, G. (2012). Demarcation of Protection Perimeters for Surface Water of Taabo (Côte d'Ivoire) Watershed Using GIS and Multicriteria Analysis. Environmental Engineering and Management Journal, 11-12, 2123-2131. https://doi.org/10.30638/eemj.2012.264

Berron, H. (1979). La pêche. In Atlas de Côte d'Ivoire $(27$ p.). Ministère du Plan/ORSTOM/Institut de Géographie Tropicale, Partie C4b.

Bonn, F., \& Rochon, G. (1992). Précis de télédétection. Volume 1. Principes et méthodes (485 p.). Québec: Presse Universitaire de Québec, Agence Universitaire de la Francophonie.

Delor, C., Diaby, I., Simeon, Y., Yao, B., Tastet, J. P., Vidal, M., Chiron, J. C., \& Dommanget, A. (1992). Notice explicative de la carte géologique de la Côte d'Ivoire au 1/200000. Feuille de Grand-Bassam (30 p.). Mémoire de Géologie de Côte d'Ivoire No. 4.

Dibi, B. (2008). Cartographie des sites potentiels d'implantation des points d'eau dans le département d'Aboisso (Sud-Est de la Côte d'Ivoire): Apport du SIG et de l'analyse multicritère (156 p.). Thesis, Abidjan: Cocody-Abidjan University.

Douay, D., \& Lardieg, E. (2010). Délimitation des Aires d'Alimentation des captages prioritaires du bassin Adour Garonne, Méthodologie de cartographie de la vulnérabilité intrinsèque des captages d'eau superficielle (28 p.).

Edoukou, J. D., Kouame, K. J., Deh, K. S., Abinan, A. T., \& Jourda, J. P. (2016). Contribution of the Sensitivity Analysis in Groundwater Vulnerability Assessing Using the DRASTIC Method: Application to Groundwater in Dabou Region (Southern of Côte d'Ivoire). Journal of Environmental Protection, 7, 129-143. https://doi.org/10.4236/jep.2016.71012

Garouni, E. A., \& Merzouk, A. (2006). Délimitation des zones de protection autour de la retenue du barrage Hachef (Maroc) par télédétection et SIG. Revue des Sciences de l'eau, 19, 1-10. https://doi.org/10.7202/012170ar

Geomines (1982). Inventaire hydrogéologique appliqué à l'hydraulique villageoise (29p.). Carte de Grand-Bassam, Cahier n ${ }^{\circ} 31$, Annexe 1.

Haouchine, A., Boudoukha, A., Fatima, Z. H., \& Rachid, N. (2010). Cartographie de la recharge potentielle des aquifères en zone aride. Eurojournals, 45, 1-13.

INS (2014). Recensement Général de la Population et de l'Habitat: Résultats globaux (22 p.).

Jourda, J. P., Kouame, K. J., Adja, M. G., Deh, S. K., Anani, A. T., Effini, A. T., \& Biemi, J. (2007). Evaluation du degré de protection des eaux souterraines: vulnérabilité à la pollution de la nappe de Bonoua (Sud-Est de la Côte d'Ivoire) par la méthode DRASTIC. Acte de conférence Francophone ESRI Versailles (18 p.).

Keita, M. (1999). Etude structurale de la shear zone de l'AFEMA, région d'Aboisso (SE de la Côte d'Ivoire) (65 p.). Mémoire de DEA des Sciences de la Terre, Abidjan: Université de Cocody.

Koffi, A. B. (2016). Détermination des zones de recharge de la nappe de Bonoua: Approche cartographique et SIG (70 p.). Mémoire de Master, Abidjan: Université Felix 
Houphouët Boigny.

Kouame, K. J. (2007). Contribution à la Gestion Intégrée des Ressources en Eaux GIRE) du District d'Abidjan (Sud de la Côte d'Ivoire): Outils d'aide à la décision pour la prévention et la protection des eaux souterraines contre la pollution (222 p.). $\mathrm{PhD}$ Thesis, Cocody-Abidjan.

Koudou, A., Adiaffi, B., Assoma, T. V., Sombo, A., Amani, E. M. E., \& Biemi, J. (2013). Conception d'un outil d'aide à la décision pour la prospection des eaux souterraines en zone de socle du Sud-Est de la Côte d'Ivoire. GeoEcoTrop Journal, 37, 211-226.

Lachassagne, P., Wyns, R., Berard, P., Bruel, T., Chery, L., Coutand, T., Desprats, J. F., \& Le Strat, P. (2001). Exploitation of High-Yield in Hard-Rock Aquifers: Downscaling Methodology Combining GIS and Multicriteria Analysis to Delimate Field Prospecting Zones. Ground Water, 39, 568-581. https://doi.org/10.1111/j.1745-6584.2001.tb02345.x

Michele, P, Anne, S. M., \& Sarah, D. (2011). Guide d'évaluation des sources d'approvisionnement en eau potable (230 p.).

Moussa, D. (2006). L'apport du Système d'Information Géographique (SIG) dans la gestion de l'épidémiologie du VIH SIDA en Côte d'Ivoire: Cas du Département d'Aboisso dans la région du Sud-Comoé(206 p.). PhD Thesis, Cocody-Abidjan.

Oularé, S., Kouamé, F. K., Saley, M. B., Aké, G. É., Adja, G. M., Kouamé, A. K., \& Therrien, R. (2014). Estimation et validation de la profondeur des nappes du bassin du N'zo, en Côte d'Ivoire, par le modèle WTR. Physio-Geo, Géographie, Physique, et Environnement, 8, 1-25. https://doi.org/10.4000/physio-geo.3752

Perraud et De La Souchere (1971). Esquisse pédologique de la Côte d'Ivoire à l'échelle de 1/500000. Feuille Sud-Est. Édit. ORSTOM, Centre d'Adiopodoumé.

Saaty, T. L. (1977). A Scaling Method for Priorities in Hierachical Structures. Journal of Mathematical Psychology, 15, 234-281. https://doi.org/10.1016/0022-2496(77)90033-5

Saaty, T. L. (1980). The Analytic Hierarchy Process: Planning, Priority Setting, Resource Allocation (19 p.). New York: McGraw-Hill.

Salama, R., Tapley, I., Ishii, T., \& Hawkes, G. (1994). Identification of Areas of Recharge and Discharge Using Landsat-TM Satellite Imagery and Aerial Photography Mapping Techniques. Journal of Hydrology, 162, 119-141.

https://doi.org/10.1016/0022-1694(94)90007-8

Saley, M. B. (2003). Système d'informations hydrogéologiques a référence spatiale, discontinuités pseudo-images et cartographies thématiques des ressources en eau de la région semi-montagneuse de Man (Ouest de la Cote d' Ivoire) (195p.). PhD Thesis, Abidjan: Cocody-Abidjan University.

Shaban, A., Khawlie, M., \& Abdallah, C. (2006). Use of Remote Sensing and GIS to Determine Recharge Potential Zone: The Case of Occidental Lebanon. Hydrogeology Journal, 14, 433-443. https://doi.org/10.1007/s10040-005-0437-6

Sophocleous, M. (2004). Groundwater Recharge and the Water Budgets of the Kansas High Plains and Related Aquifers. Kansas Geological Survey Bulletin, 249, 102 p.

Yeh, H.-F., Lee, C.-H., Hsu, K.-C., \& Chang, P.-S. (2009). GIS for Assessment of Groundwater Recharge Potential Zone. Environmental Geology, 58, 185-195. https://doi.org/10.1007/s00254-008-1504-9 